\title{
EDITORS FOREWORD
}

\author{
MATEUS BERNARDES ${ }^{1}$, IGOR LEITE FREIRE², MARIA CECILIA ZANARDI ${ }^{3}$
}

${ }^{1}$ DAMAT - Depto. Acadêmico de Matemática, UTFPR - 80230-901, Curitiba, PR. E-mail: mbernardes@utfpr.edu.br

${ }^{2}$ CMCC - Centro de Matemática, Computação e Cognição, UFABC. E-mail: igor.freire@ufabc.edu.br

${ }^{3}$ CECS - Centro de Engenharia, Modelagem e Ciências Sociais 09210-170, Santo André, SP. E-mail: mceciliazanardi@gmail.com

The number of events sponsored and supported by SBMAC has grown in the past few years. Ten years ago the Society had essentially a CNMAC (Congresso Nacional de Matemática Aplicada e Computacional) every year and some local events, the ERMACs (Encontros Regionais de Matemática Aplicada e Computacional). Currently, the Brazilian biggest event in Applied Mathematics, the CNMAC, is biennial, but now there are big regional events, corresponding to the geographical Brazil's division, the CMACs (Congressos de Matemática Aplicada e Computacional).

Moreover, there are the ERMACs, and also a lot of other sponsored events, some of them jointly with other scientific societies.

It is clear that these events deserve a place with a good visibility for publishing the presented papers. Having these points in mind, SBMAC decided to create a new publication, called Proceeding Series of the Brazilian Society of Computational and Applied Mathematics, the Proceedings of SBMAC, for short.

The idea of the Proceedings of SBMAC is that any sponsored event by SBMAC can find here a place for publishing its works. Proceedings of SBMAC should not be considered as a journal.

This is not the idea. It is a place in which the accepted and presented works in the events can be published as proceedings like every good conference around the world does. This is the spirit of the publication: a vehicle for publishing papers from events sponsored by SBMAC with an wide audience.

Here we are, at the first issue, of the first volume. This is a historical publication! And for this historical publication, we are pleased to present the works of the Brazilian Conference of Dynamics, Control and Applications - DINCON 2013, which occurred on October, 13-17, 2013, at Fortaleza-CE. The objective of DINCON is to hold a forum for discussion for new and non-classical approaches for modeling and controling nonlinear dynamics systems and applications.

Many renowned international researchers, as well as young ones, attended the DINCON 2013 and their papers are published in this Proceeding.

On behalf of the whole Editorial Board, we would like to show our gratitude for the Direction of SBMAC, for having trusted us the first Editorial Board of the Proceedings of SBMAC. We are also thankful to Geraldo Nunes Silva for helping us in the practical aspects of the publication.

We are also indebted to Elbert Einstein Nehrer Macau for taking care about this first issue of the Proceeding Series of the Brazilian Society of Computational and Applied Mathematics.

Everyone is invited to enjoy this first publication of the Proceeding Series of the Brazilian Society of Computational and Applied Mathematics! 